\title{
The staphylococcal accessory regulator, SarA, is an RNA-binding protein that modulates the mRNA turnover properties of late-exponential and stationary phase Staphylococcus aureus cells
}

\author{
John M. Morrison ${ }^{1}$, Kelsi L. Anderson ${ }^{1}$, Karen E. Beenken ${ }^{2}$, Mark S. Smeltzer $^{2}$ and Paul M. Dunman ${ }^{1,3 *}$ \\ 1 Department of Pathology and Microbiology, University of Nebraska Medical Center, Omaha, NE, USA \\ 2 Department of Microbiology and Immunology, University of Arkansas for Medical Sciences, Little Rock, AR, USA \\ ${ }^{3}$ Department of Microbiology and Immunology, School of Medicine and Dentistry, University of Rochester, Rochester, NY, USA
}

Edited by:

David Heinrichs, University of

Western Ontario, Canada

\section{Reviewed by:}

Mark Estes, University of Georgia, USA

Sebastien P. Faucher, McGill

University, Canada

Pierre Fechter, Centre National de la

Recherche Scientifique, France

Tom Geissmann, Institue de Santé et

Recherche Médicale, France

*Correspondence:

Paul M. Dunman, Department of Microbiology and Immunology,

University of Rochester School of Medicine and Dentistry, 601

Elmwood Avenue, Box 672,

Rochester, NY 14642, USA

e-mail:paul_dunman@urmc.

rochester.edu

\begin{abstract}
The modulation of mRNA turnover is gaining recognition as a mechanism by which Staphylococcus aureus regulates gene expression, but the factors that orchestrate alterations in transcript degradation are poorly understood. In that regard, we previously found that 138 mRNA species, including transcripts coding for the virulence factors protein A (spa) and collagen-binding protein (cna), are stabilized in a sarA-dependent manner during exponential phase growth, suggesting that SarA directly or indirectly affects the RNA turnover properties of these transcripts. Herein, we expanded our characterization of the effects of sarA on mRNA turnover during late-exponential and stationary phases of growth. Results revealed that the locus affects the RNA degradation properties of cells during both growth phases. Further, using gel mobility shift assays and RIP-Chip, it was found that SarA protein is capable of binding mRNA species that it stabilizes both in vitro and within bacterial cells. Taken together, these results suggest that SarA post-transcriptionally regulates $S$. aureus gene expression in a manner that involves binding to and consequently altering the mRNA turnover properties of target transcripts.
\end{abstract}

Keywords: Staphylococcus aureus, SarA, RNA degradation

\section{INTRODUCTION}

Staphylococcus aureus is a human pathogen that causes nosocomial and community-associated infections that result in high rates of morbidity and mortality (Klevens et al., 2007; Deleo et al., 2010). The organism largely owes its ability to cause infection to the production of an array of virulence factors which, in the laboratory setting, are coordinately regulated in a cell densitydependent manner. Cell surface-associated factors are predominantly expressed during exponential phase growth whereas extracellular factors are predominantly produced during stationary phase growth (Novick, 2003; Bronner et al., 2004). The organism's virulence factors are also coordinately regulated in response to endogenous and exogenous cues, including cellular stresses and sub-inhibitory concentrations of antibiotics. A plethora of two component regulatory systems (TCRS) and nucleic acid-binding proteins have been hypothesized to modulate $S$. aureus virulence factor expression.

Of the 17 TCRS identified in $S$. aureus to date, the bestcharacterized is the accessory gene regulator (agr) locus. The agr locus encodes a quorum-sensing TCRS, AgrAC, whose regulatory effects are generally thought to be mediated by a regulatory RNA molecule, RNAIII. Within laboratory culture conditions, RNAIII expression peaks during the transition to stationary phase growth
(Novick, 2003). RNAIII has been shown to modulate virulence factor expression by directly binding to target mRNA species, thereby affecting their stability and translation properties (Morfeldt et al., 1995; Huntzinger et al., 2005; Geisinger et al., 2006; Boisset et al., 2007). For instance, RNAIII binding to the cell surface factor protein A (spa) transcript creates a substrate for ribonuclease III digestion, which, in-turn, accelerates spa mRNA digestion and consequently limits Spa production (Huntzinger et al., 2005). Conversely, the binding of RNAIII to the extracellular virulence factor $\alpha$-hemolysin (hla) transcript liberates the mRNA's ShineDalgarno sequence and increases Hla production (Morfeldt et al., 1995). Similar mechanisms of RNAIII regulation have been documented for the virulence factor coa (Chevalier et al., 2010) and the regulatory locus repressor of toxins (rot; Boisset et al., 2007).

In addition to TCRS, $S$. aureus produces a family of DNAbinding proteins that regulate virulence factor expression. The best-characterized to date is the staphylococcal accessory regulator nucleic acid-binding protein, SarA. The sarA locus consists of a $1.2 \mathrm{~kb}$ DNA region that produces three overlapping transcriptional units ( $\operatorname{sar} B, \operatorname{sar} C$, and $\operatorname{sar} A$ ), each of which terminates at the same site and encodes for the SarA protein (Chien and Cheung, 1998). Unlike RNAIII, SarA is constitutively produced throughout $S$. aureus growth phases, however the expression of the individual sar 
transcripts occurs in a growth phase-dependent manner; sar $A$ and $s a r B$ are primarily transcribed during exponential phase growth whereas $\operatorname{sarC}$ is predominantly expressed during stationary phase growth (Manna et al., 1998; Blevins et al., 1999). SarA has been characterized as a pleiotropic transcriptional regulator of virulence factors that can bind to the promoter regions of a subset of genes that it regulates, such as hla ( $\alpha$-hemolysin) and spa (protein A; Chien and Cheung, 1998; Chien et al., 1999). Nonetheless, several observations have suggested that SarA's regulatory effects might be more complex than initially appreciated. Arvidson and colleagues have reported that, in addition to affecting spa transcript synthesis, SarA may also indirectly regulate Spa production (Tegmark et al., 2000). Further, no clear SarA consensus binding site has been defined; Cheung and colleagues found that SarA binds a 26 base pair (bp) region termed the SarA box, whereas Sterba et al. (2003) have defined the SarA box to be a 7 bp sequence, which is present more than 1000 times within the $S$. aureus genome, indicating that the protein may have the capability of binding the chromosome more frequently than one might expect for a bona fide transcription factor (Chien et al., 1999). In that regard, others have suggested that SarA is a histone-like protein whose regulatory effects are a function of altering DNA topology and, consequently, promoter accessibility (Schumacher et al., 2001).

In Escherichia coli, histone-like proteins can post-transcriptionally regulate gene expression by binding directly to mRNA molecules and influencing the transcript's stability and translation (Balandina et al., 2001; Brescia et al., 2004). Accordingly, based on the possibility that SarA may behave as a histone-like protein, we hypothesized that the protein's regulatory effects may, in part, be due to its ability to bind and subsequently modulate the mRNA turnover properties of target transcripts. As a first step toward testing that prediction, we found that 138 mRNA species that are produced during $S$. aureus exponential phase growth, including the known SarA-regulated genes spa and $c n a$, are also stabilized in a sarA-dependent manner (Roberts et al., 2006). More specifically, these mRNA transcripts are stabilized in a $s a r A^{+}$background as compared to isogenic $s a r A^{-}$cells, raising the possibility that SarA protein may bind these transcripts in a manner that affects their stability and, consequently, expression. In the current body of work we extended our evaluation of this phenomenon by investigating whether the mRNA turnover properties of late-exponential and/or stationary phase transcripts are also modulated in a sarAdependent manner. Results revealed that this is indeed the case; the sarA locus affects the mRNA turnover properties of transcripts produced during both phases of growth. Further, using ribonucleoprotein immunoprecipitation (RIP-Chip) assays, we found that SarA binds these transcripts within S. aureus cells. Results were verified via gel-shift mobility assays. Taken together, these results indicate that SarA is capable of binding cellular mRNA species and that the protein's regulatory effects could be attributable to its ability to directly modulate the mRNA turnover properties of target mRNA species.

\section{MATERIALS AND METHODS GROWTH CONDITIONS}

Bacterial strains and plasmids used in this study are listed in Table 1. Overnight $S$. aureus cultures were diluted 1:100 into
Table 1 | Bacterial strains and plasmids used in this study

\begin{tabular}{|c|c|c|}
\hline Strains & $\begin{array}{l}\text { Relevant genotype or } \\
\text { phenotype }\end{array}$ & Reference \\
\hline UAMS-1 & $\begin{array}{l}\text { Wild type } S \text {. aureus } \\
\text { osteomyelitis isolate }\end{array}$ & $\begin{array}{l}\text { Gillaspy et al. (1995); Cas- } \\
\text { sat et al. (2005) }\end{array}$ \\
\hline UAMS-929 & UAMS-1 ( $\Delta$ sarA) & Blevins et al. (1999) \\
\hline KLA43 & UAMS-929 (pKLA40) & This study \\
\hline RN4220 & Restriction-deficient $S$. aureus & de Azavedo et al. (1985) \\
\hline $\mathrm{INV} \alpha \mathrm{F}$ & $\begin{array}{l}\text { E. coli competent cells; } \\
\text { lacZ } \triangle \mathrm{M} 15\end{array}$ & Invitrogen \\
\hline $\mathrm{DH} 5 \alpha$ & E. coli competent cells & Invitrogen \\
\hline Plasmids & Relevant genotype & \\
\hline $\mathrm{pCR} \|$ & TOPO-TA cloning vector & Invitrogen \\
\hline pBK123 & Cam $^{R}$ derivative of $\mathrm{pCN} 51$ & Charpentier et al. (2004) \\
\hline pKLA40 & pBK123::c-Myc-SarA & This study \\
\hline
\end{tabular}

fresh brain-heart infusion $(\mathrm{BHI})$ broth with a flask to volume ratio of $5: 1$ and were incubated at $37^{\circ} \mathrm{C}$ with aeration on a rotary shaker at $225 \mathrm{rpm}$. When cultures reached mid-exponential $\left(\mathrm{OD}_{600 \mathrm{~nm}}=0.25-0.30\right)$, late-exponential $\left(\mathrm{OD}_{600 \mathrm{~nm}}=1.1-1.2\right)$, or stationary $(24 \mathrm{~h}$ post-inoculation $)$ phase, rifampicin $(200 \mu \mathrm{g}$ $\mathrm{ml}^{-1}$; Sigma; St. Louis, MO) was added to arrest transcription. Aliquots of cells were removed at $0,2.5,5,15$, and $30 \mathrm{~min}$ posttranscriptional arrest, mixed with an equi-volume of ice-cold acetone:ethanol (1:1) and RNA was isolated, as previously described (Anderson et al., 2006; Roberts et al., 2006; Olson et al., 2011).

\section{GENECHIP ${ }^{\circledR}$ MICROARRAYS}

All microarray studies were performed as previously described (Anderson et al., 2006, 2010; Roberts et al., 2006; Olson et al., 2011). Briefly, $10 \mu \mathrm{g}$ of each bacterial RNA sample was labeled and hybridized to a S. aureus GeneChip ${ }^{\circledR}$, following the manufacturer's recommendations for antisense prokaryotic arrays (Affymetrix; Santa Clara, CA). Average GeneChip ${ }^{\circledR}$ signal intensities for biological replicates $(n \geq 2)$ for each strain and time point were obtained from values normalized to exogenous transcripts. The half-life of each RNA transcript was determined using a "twofold" algorithm (Selinger et al., 2003) and was measured as the time point at which a given RNA signal intensity decreased two-fold as compared to that transcript at $0 \mathrm{~min}$ post-transcriptional arrest using GeneSpring 7.2 software (Agilent Technologies; Redwood City, CA).

\section{IN VITRO TRANSCRIPTION}

DNA templates consisting of the full-length spa transcriptional unit or derivatives containing $3^{\prime}$ or $5^{\prime}$ deletions were created by PCR amplification using UAMS-1 chromosomal DNA as a template and oligonucleotides listed in Table 2. Resulting PCR products contained a $5^{\prime}$ T7 RNA polymerase promoter and transcription start site and were used as templates for generating corresponding RNA species using a T7 MegaScript In vitro Transcription Kit (Ambion; Austin, TX) according to the manufacturer's recommendations. Briefly, for transcription reactions, approximately $1 \mu \mathrm{g}$ of PCR product was incubated for $3 \mathrm{~h}$ at $37^{\circ} \mathrm{C}$ with $7.5 \mathrm{mM}$ of a NTP mix and T7 RNA polymerase to generate the 


\begin{tabular}{|c|c|}
\hline Primer name & Sequence $\left(5^{\prime} \rightarrow 3^{\prime}\right)$ \\
\hline \multicolumn{2}{|l|}{ RT-PCR } \\
\hline cna $\mathrm{F}$ & AACGAACAAGTATACACCAGGAGAG \\
\hline norA $\mathrm{F}$ & GCAGGTGCATTAGGCATTTTAGC \\
\hline norA R & TGCCGATAAACCGAACGCTAAG \\
\hline sarA F & TTTTAACCATGGCAATTACAAAAAT \\
\hline sarA R & TTTCTCTTTGTTTTCGCTGATGTAT \\
\hline \multicolumn{2}{|c|}{ PCR-MEDIATED IN VITROTRANSCRIPTION* } \\
\hline L 1-450 spaT7 F & TAATACGACTCACTATAGGGCATACAGGGGGTATTAATTTGAAAA \\
\hline L 1-450 spa R & ATCCTAGAATTCTCTTCGTTCAAGTTAGGCATGTTCA \\
\hline \multicolumn{2}{|l|}{ CLONING ${ }^{\dagger}}$, \\
\hline c-Myc-SarA R & ATCCTAGGATCCTTACAGATCTTCTTCGCTGATCAGTTTCTGTTCTA GTTCAATTTCGTTGTTTGCTTCAGTG \\
\hline
\end{tabular}

*Bolded nucleotides indicate T7 promoter sequence.

${ }^{+}$Underlined nucleotides indicate restriction sites.

${ }^{*}$ Italicized nucleotides indicate the c-Myc epitope.

indicated RNA species. Template DNA was degraded with four units of TurboDNase I for $15 \mathrm{~min}$ at $37^{\circ} \mathrm{C}$, and in vitro transcribed RNA was recovered by lithium chloride precipitation and resuspended in nuclease-free water. RNA concentration of the synthesized product was determined spectrophotometrically $\left(\mathrm{OD}_{260} \mathrm{~nm}\right.$ $1.0=40 \mu \mathrm{g} \mathrm{ml}^{-1}$ ) and the integrity of the transcript was evaluated on a $1.2 \%$ agarose $-0.66 \mathrm{M}$ formaldehyde denaturing gel.

\section{ELECTROPHORETIC MOBILITY SHIFT ASSAY}

In vitro transcribed spa mRNA or a PCR product containing the endogenous hla promoter were $3^{\prime}$ end-labeled with digoxigenin-ddUTP (DIG; Roche Applied Science; Indianapolis IN) following the manufacturer's recommendations. One picomole DIG-mRNA or -DNA was mixed with $0,7.3,36.6,73.3$, or $366.5 \mathrm{pmol}$ purified SarA protein then, incubated for $15 \mathrm{~min}$ at $37^{\circ} \mathrm{C}$ in gel-shift buffer (20 mM HEPES-KOH, pH 8.0, $8 \mathrm{mM}$ $\mathrm{MgCl}_{2}, 100 \mathrm{mM} \mathrm{NaCl}$ ), cooled on ice and the entire sample volume was electrophoresed in $1.2 \%$ agarose $-0.66 \mathrm{M}$ formaldehyde denaturing gels. Next, RNA-protein or DNA-protein complexes were transferred via capillary action to nylon membranes overnight in $20 \times$ SSC buffer $(3 \mathrm{M} \mathrm{NaCl}, 300 \mathrm{mM}$ sodium citrate, $\mathrm{pH}$ 7.0). Nucleic acid was then cross-linked to the membrane by UV irradiation in a Stratalinker ${ }^{\circledR} \mathrm{UV}$ crosslinker (Stratagene; La Jolla, CA) twice at $1200(\times 100)$ microjoules. Membranes were probed for presence of the DIG-labeled RNA or DNA using anti-DIG Fab fragments conjugated to alkaline phosphatase (1:10,000; Roche Applied Science) and visualized chemiluminescently with CSPD reagent (Roche Applied Science). For all binding assays, bovine serum albumin (BSA) was used as a negative control for non-specific RNA-protein and DNA-protein interactions.

\section{c-Myc-SarA CONSTRUCTION}

A c-Myc epitope was translationally fused to the C-terminus of the SarA open reading frame. To do so, $615 \mathrm{bp}$ of the S. aureus strain UAMS-1 sarA gene and its corresponding P1 promoter region were amplified by PCR using primers c-Myc-SarA F and c-Myc-SarA R (Table 2); the latter included a c-Myc epitope and $3^{\prime}$ flanking restriction enzyme site. The resultant PCR product was gel-purified and digested with restriction enzymes SalI and BamHI and subcloned into pBK123 (Charpentier et al., 2004) to generate the plasmid pKLA40. Plasmid pKLA40 was then electroporated into the restriction-negative strain of $S$. aureus, RN4220 (de Azavedo et al., 1985) and transfected into UAMS-929 $(\Delta$ sarA $)$ via $\varphi 11$-mediated phage to generate strain KLA43 and the plasmid was sequenced to confirm the integrity of the insert. c-MycSarA functionality was confirmed by examining the ability of the epitope-tagged protein to complement the exoprotein profile of UAMS-929 $\triangle \triangle$ sarA $)$ cells. Briefly, supernates from stationary phase cultures of $S$. aureus UAMS-1, UAMS- $929(\Delta$ sarA), and KLA43 $(\triangle \operatorname{sar} A ; \mathrm{c}-\mathrm{Myc}$-SarA) were collected, filtered through a $0.22 \mu \mathrm{m}$ nylon membrane, and compared by electrophoresis in sodium dodecyl sulfate-polyacrylamide gels and silver staining (Bio-Rad Life Science, Hercules, CA).

\section{WESTERN BLOTTING}

Cultures were grown to the indicated growth phase and cells were mechanically disrupted in TE buffer in BIO101 lysing matrix B tubes using a FastPrep120 shaker (MP Biomedicals; Solon OH). Cell debris was removed by centrifugation at $4^{\circ} \mathrm{C}$ for $15 \mathrm{~min}$ and the protein concentration of supernatants were quantified by Bradford protein assays. For confirmation of c-Myc-SarA expression, $1 \mu \mathrm{g}$ of protein was electrophoresed in a $15 \%$ sodium dodecyl 
sulfate-polyacrylamide gels and transferred to polyvinylidene fluoride membranes. Membranes were blocked with $10 \%$ milk in Tween-TBS (TTBS; TBS containing 0.1\% Tween 20) and rabbit polyclonal anti-c-Myc antibody (1:1000; Sigma Aldrich; St. Louis, $\mathrm{MO})$ was used to probe for presence of the c-Myc-SarA protein. Following incubation with the primary antibody, membranes were washed in TTBS and probed with peroxidase-conjugated anti-rabbit secondary antibody (1:1000; Promega; Madison, WI). Membranes were washed and c-Myc-SarA was detected chemiluminescently by ECL ${ }^{\mathrm{TM}}$ (Amersham BioSciences; Piscataway NJ). Confirmation of successful RIP was confirmed by loading $10 \mu \mathrm{l}$ of cell lysate, cell supernate, wash, or elution fractions and subjected to SDS-PAGE and western blotting, as described above.

\section{RIBONUCLEOPROTEIN IMMUNOPRECIPITATION (RIP-Chip)}

Ribonucleoprotein immunoprecipitation was performed using a c-Myc Tag/Co-IP Kit (Pierce Biotechnology; Rockford, IL). To do so, S. aureus strains UAMS-929 ( $\triangle$ sarA; negative control) and KLA43 ( $\Delta$ sarA/pKLA40::c-Myc-SarA) were grown to midexponential phase and RNA-binding proteins were cross-linked to RNA by incubating the cells for $30 \mathrm{~min}$ with $1 \%$ formaldehyde at room temperature. Cross-linking was quenched by adding $125 \mathrm{mM}$ glycine for $5 \mathrm{~min}$ at room temperature. Cells were centrifuged at $3000 \mathrm{RPM}$ for $10 \mathrm{~min}$ at $4^{\circ} \mathrm{C}$ and cell pellets were washed twice in $1 \mathrm{ml}$ ice-cold TBS, resuspended in $350 \mu \mathrm{l}$ of lysis buffer (10 mM Tris pH 8.0, $10 \mathrm{mM}$ EDTA, $50 \mathrm{mM} \mathrm{NaCl}$, and $1 \mathrm{mM}$ PMSF) and were lysed by the addition $100 \mu \mathrm{g} \mathrm{ml}^{-1}$ lysostaphin (Ambi; Lawrence, $\mathrm{NY}$ ) at $37^{\circ} \mathrm{C}$ for $30 \mathrm{~min}$. Next, an equal volume of $2 \times$ immunoprecipitation (IP) buffer (100 mM Tris pH 8.0, $10 \mathrm{mM}$ EDTA, $300 \mathrm{mM} \mathrm{NaCl}$, 2\% Triton X-100, 1 mM PMSF) was added and suspensions were incubated for an additional $10 \mathrm{~min}$ at $37^{\circ} \mathrm{C}$. Nucleic acids were fragmented with a Sonic Dismembrator (Fisher) on ice twice for $15 \mathrm{~s}$ using an output setting of one with $15 \mathrm{~s}$ rests on ice between each pulse and cell debris was subsequently removed by centrifugation for $10 \mathrm{~min}$ at $4^{\circ} \mathrm{C}$. Next, $800 \mu \mathrm{l}$ of the supernatant was mixed with $10 \mu \mathrm{l}$ of anti-c-Myc agarose (Pierce Biotechnology; Rockford IL) and then added to IP spin columns (Pierce Biotechnology) and incubated overnight at $4^{\circ} \mathrm{C}$ to collect c-Myc-SarA/RNA and DNA complexes. Columns were washed five times with $1 \times$ IP buffer and c-Myc-SarA complexes were eluted in $50 \mu \mathrm{l}$ of elution buffer $(50 \mathrm{mM}$ Tris $\mathrm{pH} 8.0$, $10 \mathrm{mM}$ EDTA, $1 \%$ SDS) by first incubating at $65^{\circ} \mathrm{C}$ for 10 in followed by centrifugation at $4^{\circ} \mathrm{C}$ to collect eluate. Cross-linking was reversed by incubating eluate for $2 \mathrm{~h}$ at $42^{\circ} \mathrm{C}$ and then $6 \mathrm{~h}$ at $65^{\circ} \mathrm{C}$ in $0.5 \times$ elution buffer containing $0.8 \mathrm{mg} \mathrm{ml}^{-1}$ pronase. For chromatin immunoprecipitation (ChIP-chip) experiments used to detect known SarA-DNA interactions, liberated DNA was purified using a PCR Clean-Up Kit (Qiagen) per manufacturer's recommendations and hybridized to a GeneChip ${ }^{\circledR}$ and processed as described above. For RIP-chIP experiments, liberated nucleic acid was treated with $17 \mathrm{U}$ of RNase-Free DNase I (Qiagen) and RNA was purified using a Clean and Concentrator Kit (Zymo Research; Orange, CA) according to the manufacturer's recommendations. All assays were performed in triplicate for each strain and purification of the c-Myc-SarA protein was confirmed via Western blotting. Following IP, bacterial RNA was amplified and reversetranscribed using a MessageAmp II-Bacteria Prokaryotic RNA
Amplification Kit (Ambion). $1.5 \mu \mathrm{g}$ of the amplified cDNA was then hybridized to a GeneChip ${ }^{\circledR}$ and processed as described above. The fold change in average signal intensity of KLA43 replicates as compared to the average signal intensity of UAMS-929 (negative control) replicates was calculated for each GeneChip ${ }^{\circledR}$ qualifier. SarA was considered to bind DNA or transcripts that exhibited a signal intensity that was $\geq$ two-fold in KLA43 samples and greater than two standard deviations from the average signal intensity (background), as compared to UAMS-929 cells.

\section{QUANTITATIVE REVERSE-TRANSCRIPTION PCR}

For standard qRT-PCR reactions, $25 \mathrm{ng}$ of total bacterial RNA were reverse-transcribed, amplified, and measured using a LightCycler ${ }^{\circledR}$ RNA Master SYBR Green I kit per the manufacturer's recommendations (Roche Applied Science). As an internal control by which to standardize RNA loading, $0.5 \mathrm{pg}$ of RNA was used to quantitate the amount of $16 \mathrm{~S}$ rRNA in each sample. Transcript concentrations were calculated using LightCycler ${ }^{\circledR}$ software and LightCycler ${ }^{\circledR}$ Control Cytokine RNA titration kit as a standard for determining the copies of each transcript present per reaction. Final concentration values are listed as normalized to $16 \mathrm{~S}$ rRNA abundance. Transcript half-lives were calculated as the time point at which RNA titers exhibited $a \geq$ two-fold decrease in signal intensity.

\section{RESULTS}

It is well recognized that SarA is a pleiotropic regulator of $S$. aureus virulence factors, yet the mechanism(s) by which the protein affects gene expression is incompletely understood. Several studies have shown that the molecule affects the transcript synthesis of target genes, however the lack of a consensus SarA-binding sequence and evidence of indirect control of gene expression have implicated SarA in post-transcriptional control of gene expression. Accordingly, it has also been hypothesized that SarA regulates $S$. aureus gene expression via modulating the mRNA turnover properties of target transcripts. In support of this hypothesis, we have previously shown that 138 mRNA species, including the virulence factor transcripts protein A $(s p a)$ and collagen-binding protein (cna) are stabilized in a sarA-dependent manner (Roberts et al., 2006). Our current efforts are designed to expand upon these initial studies and further define the role for sarA in modulating mRNA turnover.

\section{SArA STABILIZES SUBSETS OF mRNA SPECIES IN A GROWTH PHASE-DEPENDENT MANNER}

Herein, we set out to establish whether the degradation properties of mRNA species that are expressed during late-exponential and/or stationary phase growth are affected by a product of the sarA locus. To do so, S. aureus UAMS-1 (wild type) and UAMS929 (UAMS-1 $\Delta$ sarA) were grown to late-exponential or stationary phase growth and transcription was halted by the addition of rifampicin. Total bacterial RNA was then purified from aliquots of cells at $0,2.5,5,15$, and 30 min post-transcriptional arrest and the mRNA titers of expressed transcripts were then measured using Affymetrix GeneChips ${ }^{\circledR}$. A comparsion of each transcript's titer at $0 \mathrm{~min}$ post-transcriptional arrest to that of each subsequent time point allowed the half-lives of each mRNA to be measured, as 
previously described (Anderson et al., 2006, 2010; Roberts et al., 2006; Olson et al., 2011).

As shown in Figure 1, in general terms, the global RNA turnover properties of UAMS-1 and UAMS-1 1 sarA cells exhibited a similar trend that is consistent with our previous observations; bulk mRNA turnover occurs more rapidly in exponential phase as compared to stationary phase cells (Olson et al., 2011). Despite these similarities, a more detailed analysis of RNA degradation properties of individual mRNA species within each strain background indicated that sarA influences the stability of many transcripts. More specifically, 93.2 and $48.4 \%$ of transcripts exhibited halflives of $<2.5 \mathrm{~min}$ during late-exponential and stationary phase growth, respectively, in the wild type strain (Table 3 ). Conversely, 76.9 and $32.5 \%$ of transcripts were degraded within $2.5 \mathrm{~min}$ in late-exponential and stationary phase $\Delta$ sarA cells, suggesting that

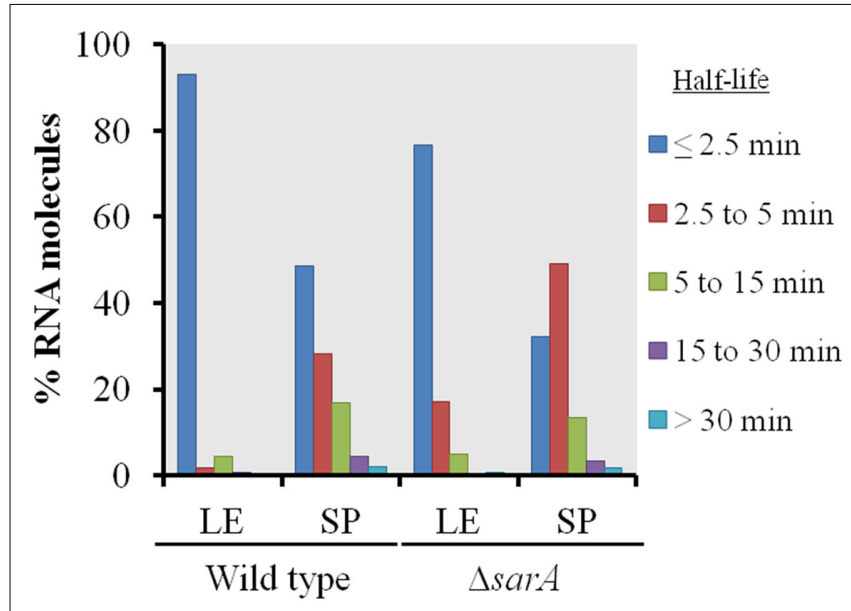

FIGURE 1 | Global transcript turnover properties of wild type and $\Delta$ sarA cells. The global RNA turnover properties of UAMS-1 (wild type) and isogenic $\Delta$ sarA ( $\Delta$ sarA) cells during late-exponential (LE) and stationary phase (SP) growth are graphed. Percentages of total transcripts with half-lives of $\leq 2.5,2.5-5,5-15,15-30$, and $\geq 30 \mathrm{~min}$ are shown.
sarA affects the stability of a subset of transcripts. Within this subset, 68 (3.2\%; Supplemental Table S1 in Supplementary Material) and 325 (15.3\%; Supplemental Table S2 in Supplementary Material) of late-log and stationary phase transcripts, respectively, were less stable in $\triangle$ sarA cells, indicating that they are stabilized in a sarA-dependent manner. Conversely, 385 (18.2\%; Supplemental Table S3 in Supplementary Material) and 580 (27.2\%; Supplemental Table S4 in Supplementary Material) of transcripts were more stable in $\Delta$ sarA cells, indicating that, like RNAIII, SarA may facilitate degradation of a particular subset of mRNA species.

\section{sarA AFFECTS VIRULENCE FACTOR mRNA STABILITY}

Results also indicated that the mRNA turnover properties of many virulence factors are influenced by $\operatorname{sar} A$, but that these effects predominantly occur during stationary phase growth. More specifically, during late-exponential phase growth the transcripts coding for three virulence-associated genes were stabilized in a sarA-dependent manner (Table 4). Among these were two metabolic enzymes, enolase (eno; Carneiro et al., 2004) and carbamate kinase (arc; Beenken et al., 2004; Diep et al., 2006; Diep and Otto, 2008), both of which exhibited half-lives of $30 \mathrm{~min}$ in wild type cells but only $15 \mathrm{~min}$ in $\Delta$ sarA cells. Likewise, the ATP-dependent protease $c l p P$ (Frees et al., 2003, 2005; Michel et al., 2006), exhibited a half-life of $15 \mathrm{~min}$ in wild type cells, but was reduced to five min in the sarA-mutant. During stationary phase growth at least 13 virulence factor transcripts were stabilized in a sarA-dependent manner (Table 4). Included among these were: spa (protein A), $h l a$ ( $\alpha$-hemolysin), hlb ( $\beta$-hemolysin), and $h l g C B$ ( $\gamma$-hemolysin), as well as members of the capsule operon (cap) and the cell surfaceassociated factors $f n b A$ (encoding fibronectin binding protein A) and cna (encoding a collagen-binding protein). Quantitative RT-PCR-based determination of select virulence factor half-lives within stationary phase wild type and $\Delta$ sarA cells verified the microarray-based RNA turnover measures (Table 5). In addition to virulence factors, three virulence factor regulatory molecules, agrA, sarS, and saeS, were stabilized in a sarA-dependent manner.

Table 3 | S. aureus growth phase mRNA degradation

UAMS-1

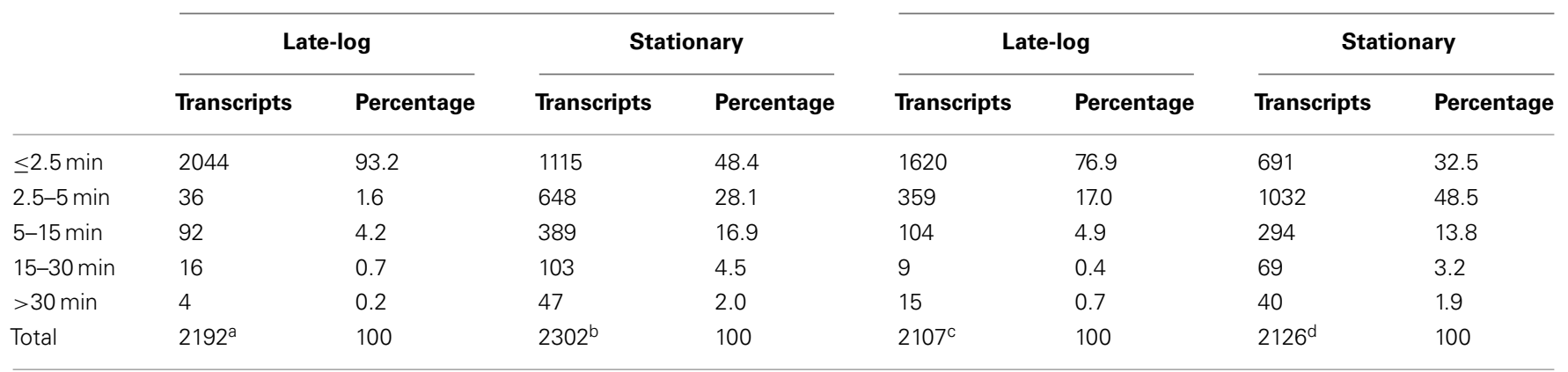

a 55 RNA species could not be measured.

${ }^{b} 27$ RNA species could not be measured.

c 38 RNA species could not be measured.

¿18 RNA species could not be measured. 
Table 4 | sarA-stabilized virulence-associated transcripts

\begin{tabular}{|c|c|c|c|}
\hline \multirow{2}{*}{$\begin{array}{l}\text { Common } \\
\text { name }^{\dagger \neq}\end{array}$} & \multicolumn{2}{|c|}{ Half-life* } & \multirow[t]{2}{*}{ Description } \\
\hline & $\begin{array}{l}\text { Wild } \\
\text { type }\end{array}$ & $\Delta$ sarA & \\
\hline \multicolumn{4}{|c|}{ LATE-EXPONENTIAL } \\
\hline $\operatorname{arc} C$ & $30 \mathrm{~min}$ & $15 \min$ & Carbamate kinase \\
\hline$c / p P$ & $15 \min$ & $5 \mathrm{~min}$ & ATP-dependent protease \\
\hline eno & $30 \min ^{*}$ & $15 \min$ & Enolase \\
\hline$s p a^{\ddagger}$ & Stable* & Stable* & Protein A \\
\hline \multicolumn{4}{|c|}{ STATIONARY } \\
\hline $\operatorname{agr} A$ & Stable* & $30 \mathrm{~min}$ & AgrAC TCRS response regulator \\
\hline $\operatorname{arcB}$ & $15 \min$ & $5 \min$ & Ornithine carbamoyltransferase \\
\hline cap5A & $5 \min$ & $2.5 \mathrm{~min}$ & Capsular polysaccharide biosynthesis \\
\hline cap5C & $15 \min$ & $5 \mathrm{~min}$ & Capsular polysaccharide biosynthesis \\
\hline cap5D & $15 \min$ & $5 \min$ & Capsular polysaccharide biosynthesis \\
\hline cna & $15 \min$ & $5 \mathrm{~min}$ & Collagen-binding protein \\
\hline$f n b A$ & $15 \min$ & $5 \mathrm{~min}$ & Fibronectin binding protein A \\
\hline hla & Stable & $30 \mathrm{~min}$ & $\alpha$-hemolysin \\
\hline$h / b$ & $30 \min$ & $15 \min$ & Phospholipase C \\
\hline$h \lg B$ & $30 \mathrm{~min}$ & $15 \min$ & $\gamma$ hemolysin component B \\
\hline$h \lg C$ & $15 \min$ & $5 \mathrm{~min}$ & $\gamma$ hemolysin component $\mathrm{C}$ \\
\hline norA & $15 \min$ & $5 \mathrm{~min}$ & Multi drug transporter \\
\hline rsbV & $5 \mathrm{~min}$ & $2.5 \mathrm{~min}$ & Anti-anti-sigma factor \\
\hline SACOL0390 & Stable & $30 \mathrm{~min}$ & Lipase \\
\hline saeR & $15 \min ^{*}$ & $5 \mathrm{~min}$ & SaeRS TCRS response regulator \\
\hline sarV & $5 \mathrm{~min}$ & $2.5 \mathrm{~min}$ & SarA homolog \\
\hline$s p a^{\ddagger}$ & $30 \min ^{*}$ & $15 \min ^{*}$ & Protein A \\
\hline
\end{tabular}

${ }^{*}$ Estimated half-life due to detection limits of the system.

S. aureus strain N315 loci unless otherwise noted.

Transcript synthesis affected by sarA in UAMS-1 cells (Cassat et al., 2006).

\section{SarA BINDS mRNA IN VITRO}

The results presented here are consistent with previous observations suggesting that the sarA locus affects $S$. aureus mRNA turnover properties with exponential phase cells (Roberts et al., 2006). The two most likely scenarios that could account for these observations are that a product of the sarA locus may directly interact with and subsequently affect the mRNA degradation properties of target transcripts or that SarA indirectly modulates the organism's mRNA turnover properties by regulating other factors that affect $S$. aureus RNA decay. As a preliminary means of distinguishing between these two possibilities we set out to determine whether SarA is an RNA-binding protein. To do so, electrophoretic mobility shift assays (EMSAs) were performed to investigate whether purified SarA protein directly binds to spa transcripts, an mRNA species that is stabilized in a sarA-dependent manner (Roberts et al., 2006). Accordingly, various amounts (0, 7.3, 36.6, 73.3, or $366.5 \mathrm{pmol}$ ) of purified SarA protein were incubated with DIG-labeled, in vitro transcribed spa mRNA, during experimental conditions that have previously been used to establish that SarA binds to the promoter region of the $\alpha$-hemolysin ( $h l a$ ) gene (Chien et al., 1999). As shown in Figure 2A, during these assay conditions SarA protein did indeed bind to the hla promoter region,
Table 5 | Stationary phase mRNA half-lives of selected virulence factor transcripts as calculated by qRT-PCR*

\begin{tabular}{|c|c|c|}
\hline & Wild type $^{\dagger}$ & $\Delta \operatorname{sar} A^{\dagger}$ \\
\hline \multicolumn{3}{|l|}{ spa } \\
\hline $0 \mathrm{~min}$ & 1.00 & 1.00 \\
\hline $5 \mathrm{~min}$ & 1.06 & 1.34 \\
\hline $15 \mathrm{~min}$ & 1.22 & 1.63 \\
\hline $30 \mathrm{~min}$ & 2.43 & 5.56 \\
\hline $60 \mathrm{~min}$ & 2.47 & 11.28 \\
\hline \multicolumn{3}{|l|}{ norA } \\
\hline $0 \mathrm{~min}$ & 1.00 & 1.00 \\
\hline $5 \mathrm{~min}$ & 1.45 & 3.14 \\
\hline $15 \mathrm{~min}$ & 2.20 & 3.22 \\
\hline $30 \mathrm{~min}$ & 3.14 & 6.99 \\
\hline $60 \mathrm{~min}$ & 3.20 & 5.38 \\
\hline \multicolumn{3}{|l|}{ cna } \\
\hline $0 \mathrm{~min}$ & 1.00 & 1.00 \\
\hline $5 \mathrm{~min}$ & 1.02 & 2.49 \\
\hline $15 \mathrm{~min}$ & 2.68 & 2.07 \\
\hline $30 \mathrm{~min}$ & 18.66 & 6.22 \\
\hline $60 \mathrm{~min}$ & 83.91 & 35.33 \\
\hline
\end{tabular}

*Time point corresponding to $\geq$ two-fold decrease (half-life) is shaded gray. ${ }^{\dagger}$ Values represented as fold-change normalized to MRNA titers at 0 min.

confirming that the experimental conditions are appropriate to measure SarA-nucleic acid interactions and further validating the work of Chien et al. (1999). Similarly, the EMSA revealed that SarA elicited a dose-dependent shift in mobility of labeled spa mRNA, suggesting that SarA may be capable of binding RNA molecules (Figure 2B). Gel-shift assays were also performed with BSA and a S. aureus stable RNA, SSR42 (Olson et al., 2011), to determine if non-staphylococcal proteins would bind to the in vitro transcribed mRNA and whether SarA alters the mobility of any RNA species, respectively. Results of those studies indicated that BSA did not affect the mobility of spa transcript and, likewise, that SarA did not affect the migration of in vitro transcribed SSR42 (Figure 2C).

RNA-binding proteins have been shown to bind to specific regions of target mRNAs (Folichon et al., 2003; Wang et al., 2005); to test this possibility with SarA, we used EMSAs to measure the protein's ability to bind different regions of in vitro transcribed spa mRNA: a region lacking bases $1-320$ of the $5^{\prime}$ end (L-250) and a fragment of spa containing only bases 1-450 (L 1-450; Figure 2D). As seen in Figure 2E, SarA affected the mobility of both RNA species. Further, a higher molecular weight product was observed when SarA was incubated with spa RNA fragments containing an intact $5^{\prime}$ region $(450 \mathrm{nt})$ in comparison to fragments lacking bases $1-250$ of the transcript $(1,100 \mathrm{nt})$, suggesting that the $5^{\prime}$ end of the spa transcript may harbor a greater number of SarA-binding sites than the $3^{\prime}$ terminus. Taken together, these results suggest that SarA may be capable of binding both DNA and RNA molecules.

\section{SarA BINDS mRNA IN VIVO}

Based on the observations that many exponential phase transcripts, including spa, are stabilized in a sarA-dependent manner and that SarA protein is capable of altering the mobility of $s p a$ 
A

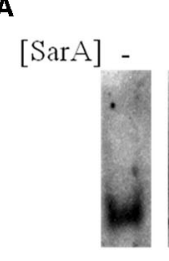

B

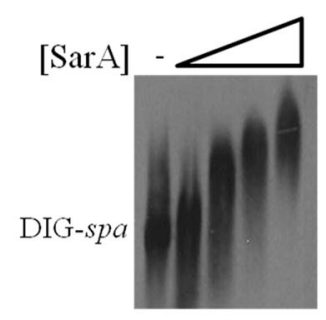

C

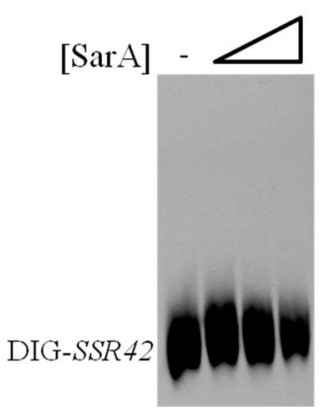

FIGURE 2 | SarA binds mRNA in vitro. (A) Gel mobility shift assays evaluating the mobility of DIG-labeled hla promoter DNA $\left(\mathrm{P}_{h l a}\right)$ in the presence of increasing amounts of purified SarA protein $(0,7.3,36.6,73.3$, or 366.5 pmol). (B) Gel mobility shift assays evaluating the mobility of DIG-labeled, in vitro transcribed spa in the presence of increasing concentrations of SarA protein (0, 7.3, 36.6, 73.3, or 366.5 pmol). (C) Gel
D

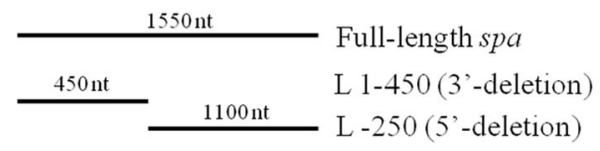

E

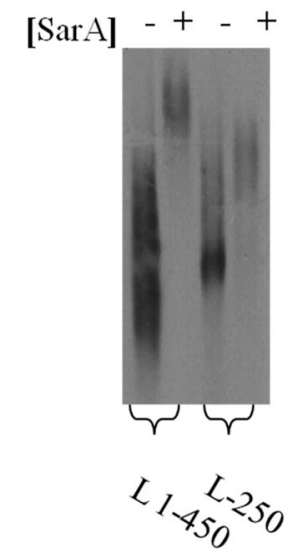

transcripts in vitro, we set out to determine whether the protein is capable of binding mRNA species within bacterial cells using ribonucleoprotein immunoprecipitation-microarray (RIP-Chip) assays. To do so, we needed to create a means of capturing cellular SarA protein. Accordingly, the SarA open reading frame was translationally fused to a C-terminal c-Myc epitope. This construct was placed under control of the sarA endogenous $\mathrm{P} 1$ promoter and was inserted into plasmid pCN51 to generate pKLA40. This plasmid was transfected into UAMS-929 ( $\triangle$ sarA $)$ cells to generate strain KLA43 and the expression properties of C-Myc-SarA protein were evaluated. It should be noted that the $\mathrm{c}-\mathrm{Myc}$ epitope has been shown to exhibit little or no non-specific nucleic acid binding in previous assays (Pannone et al., 1998). As expected, RT-PCR and Western blotting using anti-c-Myc antibodies established that the chimeric protein was expressed within KLA43 cells (Figures 3A,B) during mid- and late-exponential as well as stationary phase growth. We also confirmed that c-Myc-SarA was capable of complementing SarA's regulatory effects within $\triangle$ sarA cells. Specifically, sarA-mutant cells have been reported as exhibiting altered exprotein profiles due to alterations in the control of gene expression (Tegmark et al., 2000). Thus, we evaluated the ability of the c-Myc-SarA construct to complement the exoprotein profile of supernates from stationary phase cultures of $S$. aureus strain UAMS-929 ( $\triangle$ sarA). As shown in Figure $3 \mathrm{C}$, the c-Myc-SarA construct at least partially complemented the exoprotein profile of $\triangle$ sarA cells, indicating that presence of the epitope did not significantly affect SarA's regulatory capacity and, consequently, the chimeric protein was appropriate for studying SarA's cellular role as an RNA-binding protein.

Having confirmed that the chimeric protein was expressed and functional within $\Delta$ sarA cells, RIP-chIP assays were performed using anti-c-Myc immunoglobulin immobilized on agarose beads to capture cellular c-Myc-SarA-bound transcripts. To do so, KLA43 ( $\Delta$ sarA c-Myc-SarA) was grown to mid-exponential phase and the proteins were cross-linked to nucleic acids with $1 \%$ formaldehyde to stabilize any interactions between c-Myc-SarA and RNA molecules. Cells were lysed and c-Myc-SarA protein was then immunoprecipitated with the anti-c-Myc agarose beads, co-precipitating any bound RNA species. Western blotting of the cell lysates and RIP intermediates indicated the presence of the epitope-labeled SarA through sequential steps of the IP process (Figure 3D). After reversal of the RNA cross-linking, the RNA was 


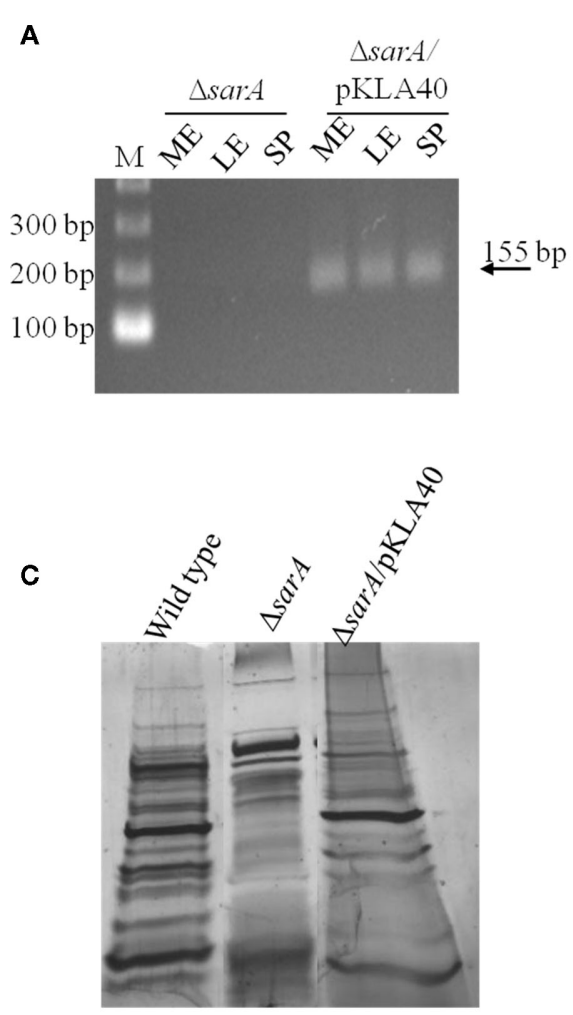

FIGURE 3 | SarA binds mRNA in vivo. (A) RT-PCR based detection of c-Myc-SarA transcript expression in $\triangle$ sarA and $\triangle$ sarA harboring plasmid pKLA40 harboring a c-Myc-SarA construct under control of the sarA P1 promoter during mid-exponential (ME), late-exponential (LE), and stationary (SP) phase growth. (B) Western blotting based detection of c-Myc-SarA chimeric protein from sarA and $\triangle$ sarA harboring plasmid pKLA40; lysates collected during mid-exponential (ME), late-exponential (LE), and stationary
B

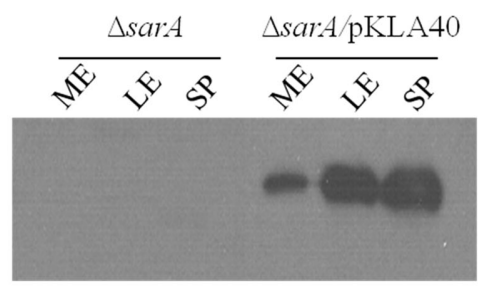

D

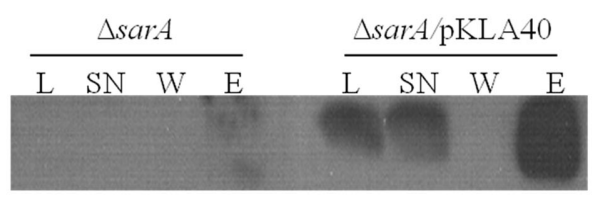

(SP) phase growth. (C) SDS-PAGE and silver staining of exoproteins purified from wild type, $\triangle$ sarA and $\triangle$ sarA harboring plasmid pKLA40 stationary phase culture supernates. (D) RNA immunoprecipitation (RIP) was performed by capturing c-Myc-SarA protein cross-linked to nucleic acids. Successful immunoprecipitation was confirmed by Western blotting of cell lysate (L), lysate supernate (SN), wash (W), and elution (E) fractions with anti-c-Myc antibody.

Table 6 | Virulence-associated transcripts bound by cellular c-Myc-SarA

purified, treated with DNase, amplified, labeled, and applied to a $S$. aureus GeneChip ${ }^{\circledR}$. All RIP-Chip assays were performed in triplicate for both KLA43 ( $\Delta$ sarA c-Myc-SarA) and $\Delta$ sarA cells (negative control). A transcript was considered to be bound by c-Myc-SarA if its average signal intensity value was $\geq$ two-fold in KLA43 cells as compared to the negative control. It should be noted that as a prerequisite to performing RIP-Chip assays we exploited SarA's known ability to bind the hla promoter region and the fact that the microarray used in this study contains intergenic regions representing gene promoters to determine whether our experimental approach was appropriate for studying cellular SarA-nucleic acid interactions. Results from ChIP-chip experiments revealed that the signal intensity of the intergenic region representing the hla promoter region exhibited a signal increase beyond the established threshold ( $\geq$ two-fold) in samples from KLA43 cells as compared to UAMS-929 cells, indicating that the experimental approach was capable of detecting known in vitro protein-nucleic acid reactions in vivo (data not shown).

RIP-Chip assays results indicated that cellular c-Myc-SarA is capable of binding to a total of 115 RNA species, including eight virulence factor transcripts (Supplemental Table S5 in Supplementary Material). Of the virulence factor transcripts bound by SarA (Table 6), spa and $\operatorname{arcB}$ were also stabilized in a $s a r A$-dependent

\begin{tabular}{|c|c|c|c|}
\hline $\begin{array}{l}\text { Common } \\
\text { name* }\end{array}$ & $\begin{array}{l}\text { Fold } \\
\text { change }^{\dagger}\end{array}$ & $\begin{array}{l}\text { mRNA } \\
\text { stability }^{\ddagger}\end{array}$ & Description \\
\hline $\operatorname{arcB}$ & 8.3 & Stabilized & Ornithine carbamoyltransferase \\
\hline pfoR & 3.7 & Destabilized & Perfringolysin $\mathrm{O}$ regulator protein \\
\hline$r s b W$ & 7.6 & & Anti-sigma B factor \\
\hline SA0097 & 8.3 & Destabilized & $\begin{array}{l}\text { Transcriptional regulator AraC/XyIS } \\
\text { family }\end{array}$ \\
\hline sarZ & 2.7 & & SarA homolog \\
\hline sbi & 3.3 & Destabilized & IgG-binding protein \\
\hline spa & 4.2 & Stabilized & IgG-binding protein A \\
\hline srtA & 7.4 & & Sortase \\
\hline
\end{tabular}

${ }^{*}$ S. aureus strain N315 locus.

${ }^{\dagger}$ Fold change of signal intensities present in c-Myc-SarA samples in comparison to $\Delta$ sarA samples $(p<0.05)$.

${ }^{\ddagger}$ Effect of sarA on transcript turnover.

manner in at least one of the growth phases studied here (latelog and stationary phase) or by our laboratory previously (midexponential phase; Roberts et al., 2006). Thus, our collective results indicate that spa mRNA is stabilized in a sarA-dependent manner 
(Roberts et al., 2006) and that SarA protein is capable of binding the transcript during in vitro conditions and within bacterial cells. When taken together, these results suggest that SarA may post-transcriptionally regulate gene expression by binding to and modulating the RNA degradation properties of target transcripts.

\section{DISCUSSION}

Staphylococci produce an array of TCRS and DNA-binding proteins that are thought to modulate virulence factor transcript synthesis, providing the pathogen with a means for sensing and responding to environmental stresses including exposure to subinhibitory concentrations of antibiotics (Novick, 2003). By definition, transcript titers are a function of both transcript synthesis and degradation, and mounting evidence strongly suggests that orchestrated changes in mRNA degradation mediate the organism's ability to regulate gene expression. Indeed, the global mRNA degradation properties of $S$. aureus are significantly altered in response to growth phase, stringent response-inducing conditions, and $\mathrm{pH}$ and temperature stress (Anderson et al., 2006, 2010; Olson et al., 2011). With respect to growth phase, RNA turnover is rapid in exponential phase cells whereas a global stabilization of RNA transcripts occurs during stationary phase growth; $\sim 90 \%$ of transcripts decay within 5 min during mid-exponential growth while only $\sim 50 \%$ of all transcripts decay within $5 \mathrm{~min}$ during stationary phase growth (Olson et al., 2011). Presently, the factors that mediate this transition between RNA degradation profiles are poorly characterized. Because all transcripts do not degrade at the same rate, it has been hypothesized that transacting factors, such as RNA-binding proteins or regulatory RNAs, may affect mRNA stability. Indeed, the mRNA turnover properties of nearly 150 exponential phase mRNA species, including the cell surface-associated virulence factors spa and cna, have been reported to be stabilized in a sarA-dependent manner (Roberts et al., 2006). However, those studies were limited in scope, in that the effects of sarA on RNA stability were only studied within mid-exponential phase cells. In the present work, we evaluated the effects of sarA on late-exponential and stationary phase RNA turnover.

A comparison of mRNA turnover within wild type and $\Delta$ sarA cells indicated that global RNA decay is similar between the two strains; mRNA is rapidly degraded in late-exponential phase cells but transcripts become more stable during stationary phase growth. Despite these similarities, transcript turnover within each growth phase was slightly decreased in $\Delta$ sarA cells indicating that a product of the sarA locus affects the stability of a subset of mRNA species. Indeed, sarA was found to both stabilize and destabilize transcripts in each growth phase; 3.4 and $16.5 \%$ of transcripts were stabilized, whereas 16.4 and $23.5 \%$ of transcripts were destabilized in a sarA-dependent manner within late-exponential and stationary phase cells, respectively. Among the stabilized transcripts were those encoding for translation machinery, suggesting that sarA may modulate protein production indirectly by posttranscriptionally altering expression of the translation apparatus. Perhaps more relevant to $S$. aureus pathogenesis, 19 virulenceassociated factors were stabilized in a sarA-dependent manner, including cell surface components, secreted enzymes and toxins, transcriptional regulators, and antibiotic resistance determinants.
Interestingly, a subset of these virulence factors, including spa, hla, sak, and $\operatorname{ss} p B$ have been previously shown to be regulated by $\operatorname{sar} A$ at the transcriptional level (Cassat et al., 2006). These results suggest that the effects of sarA on gene regulation in $S$. aureus may be more complex than previously thought, and that a product of the locus may post-transcriptionally regulate gene expression.

The sarA locus is capable of producing three distinct transcripts, each of which encode for and result in the production of SarA protein. Thus, any potential post-transcriptional regulation could occur via the SarA protein or via one of the transcribed mRNAs as has been described with other regulatory RNAs in $S$. aureus (reviewed in Felden et al., 2011). The mRNA turnover properties of $\Delta s a r A$ cells harboring plasmid-borne copies each of these three transcriptional units demonstrated that their RNA degradation properties mimicked one-another, suggesting that the SarA protein (as opposed to a particular sarA transcriptional unit) accounts for the sarA-dependent modulation of mRNA turnover (data not shown). Thus, we predicted that SarA directly or indirectly affects the RNA degradation properties of target transcripts. Accordingly, gel-shift assays were performed to determine whether SarA protein directly binds to spa mRNA in vitro, a transcript that is stabilized in a sarA-dependent manner. EMSA results revealed that SarA alters the mobility of spa mRNA in a concentrationdependent manner, suggesting that the protein is capable of binding the transcript in a cooperative manner. We hypothesize that this may reflect two potential dynamic properties of the interaction: (1) SarA oligomerizes when binding RNA or (2) the spa transcript contains multiple SarA-binding sites such that in the presence of excess SarA the number of sites bound by the protein are increased. Further, gel-shift assays indicated that SarA exhibits a greater propensity to cause a higher molecular shift of the $5^{\prime}$-end of spa mRNA, suggesting that either the $5^{\prime}$ end of the message harbors a higher incidence of SarA-binding sites or that the secondary structure of the transcript's $5^{\prime}$ end reduces the amount of steric hindrance. Regardless, we conclude from the results of these assays suggest that the SarA-mRNA interaction is not likely to be equal across the entire length of the spa transcript.

In order to characterize the physiological relevance of SarA's potential RNA-binding properties, we performed in vivo RIP-chIP assays to identify the transcripts with which the protein could interact within bacterial cells. To do so, c-Myc epitope-tagged SarA was expressed in $\triangle$ sarA cells and immunoprecipitated; c-MycSarA-bound RNA molecules were subsequently identified using GeneChips ${ }^{\circledR}$. In total, SarA was found to interact with 115 mRNA species, including eight virulence factors. Specifically, two of the virulence factor transcripts that bound to SarA in vivo were also found to be stabilized in a $s a r A$-dependent manner, including the spa transcript, an mRNA species that SarA appears to bind in vitro. Taken together, these data suggest that SarA may alter the stability of target transcripts by directly binding to these mRNA species, which could, in-turn, limit the RNA molecule's accessibility to degradation machinery. Additionally, SarA also interacted with three transcripts that are destabilized in a sarA-dependent manner, suggesting that the protein:mRNA interaction may catalyze a conformational change in the substrate RNA molecule that makes it more susceptible to ribonuclease attack. In addition to ORFs, 
SarA also bound five transcripts that mapped to intergenic regions and may represent non-coding RNA molecules.

Collectively, the data presented here indicate that SarA interacts with RNA in a biologically relevant setting and that these interactions correlate with alterations in the degradation properties of a subset of those mRNA species. Thus, we hypothesize that SarA post-transcriptionally regulates gene expression via binding to and consequently modulating the mRNA turnover properties of target transcripts. There is precedence for this prediction in other organisms. For instance, in Escherichia coli, CsrA is an RNA-binding protein that modulates virulence factor expression, in part, by both stabilizing and destabilizing target transcripts. For instance, CsrA associates with the $5^{\prime}$ untranslated region of the pgaA transcript, which blocks translation of the molecule and subsequently destabilizes the transcript (Wang et al., 2005). CsrA has also been shown to bind the flhDC transcript, stabilizing the molecule and ultimately contributes to bacterial motility (Wei et al., 2001). Given the similarities of CsrA and other RNA-binding proteins to SarA, scenarios by which SarA can post-transcriptionally modulate gene expression emerge. In the case of $s p a$, whose transcript is stabilized but protein production is repressed by SarA, binding of the RNA may simultaneously inhibit activity of the translational machinery and ribonucleases (RNases). This mechanism would presumably provide the cell with a mechanism to repress protein A production, in a manner that when inactivated would allow for efficient induction of Spa production without having to expend energy to synthesize new transcripts. Our finding that SarA seems to preferentially interact with the $5^{\prime}$ terminus of the spa transcripts supports this prediction, as the $5^{\prime}$ end of mRNA not only serves as a potential entry point for the RNA degradation machinery, it is also the loading site for the translation apparatus. Similarly, the binding of SarA to transcripts which are normally stabilized and for which protein levels are increased, SarA could function by inhibiting degradation of the transcript by RNases, thus facilitating increased production of protein. As what occurs with CsrA, SarA also destabilizes transcripts that it binds in vivo, suggesting that this interaction could expose transcripts to cleavage by RNases. It was also observed that virulence factor transcripts that were stabilized in a sarA-dependent manner were not bound by SarA in vivo (Supplemental Table S5 in Supplementary Material). Thus, one can assume that the modulation of RNA stability of these transcripts is indirect; presumably, SarA regulates another factor, such as a regulatory RNA or other RNA-binding protein, which ultimately mediates the alteration in stability. While the biological significance of sarA-dependent control of mRNA stability is not yet fully understood, these results indicate that SarA is an RNA-binding protein with the potential to post-transcriptionally regulate the mRNA and consequently protein production of target transcripts. These results may have expanded significance in that SarA represents a prototypical regulatory molecule with a multitude of homologs within S. aureus and other bacterial pathogens.

\section{ACKNOWLEDGMENTS}

This work was supported by National Institutes of Health grant AI073780 (Paul M. Dunman). John Morrison was supported by American Heart Association predoctoral award 11PRE7420020. We thank Barry Hurlburt for purified SarA protein used in the gel-shift assays.

\section{SUPPLEMENTARY MATERIAL}

The Supplementary Material for this article can be found online at http://www.frontiersin.org/Cellular_and_Infection_Microbiology /10.3389/fcimb.2012.00026/abstract

\section{Table S1 | Late-exponential phase transcripts stabilized in a sarA-dependent manner.}

Table S2 | Stationary phase transcripts stabilized in a sarA-dependent manner.

\section{Table S3 | Late-exponential phase transcripts destabilized in a sarA-dependent manner.}

Table S4 | Stationary phase transcripts destabilized in a sarA-dependent manner.

Table S5 | Mid-exponential growth phase transcripts bound by SarA in vivo.

\section{REFERENCES}

Anderson, K. L., Roberts, C., Disz, T., Vonstein, V., Hwang, K., Overbeek, R., Olson, P. D., Projan, S. J., and Dunman, P. M. (2006). Characterization of the Staphylococcus aureus heat shock, cold shock, stringent, and SOS responses and their effects on log-phase mRNA turnover. J. Bacteriol. 188, 6739-6756.

Anderson, K. L., Roux, C. M., Olson, M. W., Luong, T. T., Lee, C. Y., Olson, R., and Dunman, P. M. (2010). Characterizing the effects of inorganic acid and alkaline shock on the Staphylococcus aureus transcriptome and messenger RNA turnover. FEMS Immunol. Med. Microbiol. 60, 208-250.

Balandina, A., Claret, L., HenggeAronis, R., and Rouviere-Yaniv,
J. (2001). The Escherichia coli histone-like protein $\mathrm{HU}$ regulates rpoS translation. Mol. Microbiol. 39, 1069-1079.

Beenken, K. E., Dunman, P. M., Mcaleese, F., Macapagal, D., Murphy, E., Projan, S. J., Blevins, J. S., and Smeltzer, M. S. (2004). Global gene expression in Staphylococcus aureus biofilms. J. Bacteriol. 186, 4665-4684.

Blevins, J. S., Gillaspy, A. F., Rechtin, T. M., Hurlburt, B. K., and Smeltzer, M. S. (1999). The Staphylococcal accessory regulator (sar) represses transcription of the Staphylococcus aureus collagen adhesin gene (cna) in an agr-independent manner. Mol. Microbiol. 33, 317-326.

Boisset, S., Geissmann, T., Huntzinger, E., Fechter, P., Bendridi, N.,
Possedko, M., Chevalier, C., Helfer, A. C., Benito, Y., Jacquier, A., Gaspin, C., Vandenesch, F., and Romby, P. (2007). Staphylococcus aureus RNAIII coordinately represses the synthesis of virulence factors and the transcription regulator Rot by an antisense mechanism. Genes Dev. 21, 1353-1366.

Brescia, C. C., Kaw, M. K., and Sledjeski, D. D. (2004). The DNA binding protein $\mathrm{H}-\mathrm{NS}$ binds to and alters the stability of RNA in vitro and in vivo. J. Mol. Biol. 339, 505-514.

Bronner, S., Monteil, H., and Prevost, G. (2004). Regulation of virulence determinants in Staphylococcus aureus: complexity and applications. FEMS Microbiol. Rev. 28, 183-200.

Carneiro, C. R., Postol, E., Nomizo, R., Reis, L. F., and Brentani, R. R.
(2004). Identification of enolase as a laminin-binding protein on the surface of Staphylococcus aureus. Microbes Infect. 6, 604-608.

Cassat, J., Dunman, P. M., Murphy, E., Projan, S. J., Beenken, K. E., Palm, K. J., Yang, S. J., Rice, K. C., Bayles, K. W., and Smeltzer, M. S. (2006). Transcriptional profiling of a Staphylococcus aureus clinical isolate and its isogenic agr and sarA mutants reveals global differences in comparison to the laboratory strain RN6390. Microbiology 152, 3075-3090.

Cassat, J. E., Dunman, P. M., Mcaleese, F., Murphy, E., Projan, S. J., and Smeltzer, M. S. (2005). Comparative genomics of Staphylococcus aureus musculoskeletal isolates. J. Bacteriol. 187, 576-592. 
Charpentier, E., Anton, A. I., Barry, P., Alfonso, B., Fang, Y., and Novick, R. P. (2004). Novel cassette-based shuttle vector system for gram-positive bacteria. Appl. Environ. Microbiol. 70, 6076-6085.

Chevalier, C., Boisset, S., Romilly, C., Masquida, B., Fechter, P., Geissmann, T., Vandenesch, F., and Romby, P. (2010). Staphylococcus aureus RNAIII binds to two distant regions of coa mRNA to arrest translation and promote mRNA degradation. PLoS Pathog. 6, e1000809. doi:10.1371/journal.ppat.1000809

Chien, Y., and Cheung, A. L. (1998). Molecular interactions between two global regulators, sar and agr, in Staphylococcus aureus. J. Biol. Chem. 273, 2645-2652.

Chien, Y., Manna, A. C., Projan, S. J., and Cheung, A. L. (1999). SarA, a global regulator of virulence determinants in Staphylococcus aureus, binds to a conserved motif essential for sardependent gene regulation. J. Biol. Chem. 274, 37169-37176.

de Azavedo, J. C., Foster, T. J., Hartigan, P. J., Arbuthnott, J. P., O'reilly, M., Kreiswirth, B. N., and Novick, R. P. (1985). Expression of the cloned toxic shock syndrome toxin 1 gene (tst) in vivo with a rabbit uterine model. Infect. Immun. 50, 304-309.

Deleo, F. R., Otto, M., Kreiswirth, B. N., and Chambers, H. F. (2010). Community-associated meticillinresistant Staphylococcus aureus. Lancet 375, 1557-1568.

Diep, B. A., Gill, S. R., Chang, R. F., Phan, T. H., Chen, J. H., Davidson, M. G., Lin, F., Lin, J., Carleton, H. A., Mongodin, E. F., Sensabaugh, G. F., and PerdreauRemington, F. (2006). Complete genome sequence of USA300, an epidemic clone of community-acquired meticillin-resistant Staphylococcus aureus. Lancet 367, 731-739.

Diep, B. A., and Otto, M. (2008). The role of virulence determinants in community-associated MRSA pathogenesis. Trends Microbiol. 16, 361-369.

Felden, B., Vandenesch, F., Bouloc, P., and Romby, P. (2011). The staphylococcus aureus RNome and its commitment to virulence. PLoS Pathog. 7, e1002006. doi:10.1371/journal.ppat.1002006

Folichon, M., Arluison, V., Pellegrini, O., Huntzinger, E., Regnier, P., and Hajnsdorf, E. (2003). The poly(A) binding protein Hfq protects RNA from RNase $\mathrm{E}$ and exoribonucleolytic degradation. Nucleic Acids Res. 31, 7302-7310.

Frees, D., Qazi, S. N., Hill, P. J., and Ingmer, H. (2003). Alternative roles of ClpX and ClpP in Staphylococcus aureus stress tolerance and virulence. Mol. Microbiol. 48, 1565-1578.

Frees, D., Sorensen, K., and Ingmer, H. (2005). Global virulence regulation in Staphylococcus aureus: pinpointing the roles of ClpP and ClpX in the sar/agr regulatory network. Infect. Immun. 73, 8100-8108.

Geisinger, E., Adhikari, R. P., Jin, R., Ross, H. F., and Novick, R. P. (2006). Inhibition of rot translation by RNAIII, a key feature of agr function. Mol. Microbiol. 61, 1038-1048.

Gillaspy, A. F., Hickmon, S. G., Skinner, R. A., Thomas, J. R., Nelson, C. L., and Smeltzer, M. S. (1995). Role of the accessory gene regulator (agr) in pathogenesis of staphylococcal osteomyelitis. Infect. Immun. 63, 3373-3380.

Huntzinger, E., Boisset, S., Saveanu, C., Benito, Y., Geissmann, T., Namane, A., Lina, G., Etienne, J., Ehresmann, B., Ehresmann, C., Jacquier, A., Vandenesch, F., and Romby, P. (2005). Staphylococcus aureus RNAIII and the endoribonuclease III coordinately regulate spa gene expression. EMBO J. 24, 824-835.

Klevens, R. M., Morrison, M. A., Nadle, J., Petit, S., Gershman, K., Ray, S., Harrison, L. H., Lynfield, R., Dumyati, G., Townes, J. M., Craig, A. S., Zell, E. R., Fosheim, G. E., Mcdougal, L. K., Carey, R. B., and Fridkin, S. K. (2007). Invasive methicillin-resistant Staphylococcus aureus infections in the United States. JAMA 298, 1763-1771.

Manna, A. C., Bayer, M. G., and Cheung, A. L. (1998). Transcriptional analysis of different promoters in the sar locus in Staphylococcus aureus. J. Bacteriol. 180, 3828-3836.
Michel, A., Agerer, F., Hauck, C. R. Herrmann, M., Ullrich, J., Hacker, J., and Ohlsen, K. (2006). Global regulatory impact of $\mathrm{ClpP}$ protease of Staphylococcus aureus on regulons involved in virulence, oxidative stress response, autolysis, and DNA repair. J. Bacteriol. 188, 5783-5796.

Morfeldt, E., Taylor, D., Von Gabain, A., and Arvidson, S. (1995). Activation of alpha-toxin translation in Staphylococcus aureus by the transencoded antisense RNA, RNAIII. EMBO J. 14, 4569-4577.

Novick, R. P. (2003). Autoinduction and signal transduction in the regulation of staphylococcal virulence. Mol. Microbiol. 48, 1429-1449.

Olson, P. D., Kuechenmeister, L. J., Anderson, K. L., Daily, S., Beenken, K. E., Roux, C. M., Reniere, M. L., Lewis, T. L., Weiss, W. J., Pulse, M., Nguyen, P., Simecka, J. W., Morrison, J. M., Sayood, K., Asojo, O. A., Smeltzer, M. S., Skaar, E. P. and Dunman, P. M. (2011). Small molecule inhibitors of Staphylococcus aureus RnpA alter cellular mRNA turnover, exhibit antimicrobial activity, and attenuate pathogenesis. PLoS Pathog. 7, e1001287. doi:10.1371/journal.ppat.1001287

Pannone, B. K., Xue, D., and Wolin, S. L. (1998). A role for the yeast La protein in U6 snRNP assembly: evidence that the La protein is a molecular chaperone for RNA polymerase III transcripts. EMBO J. 17, 7442-7453.

Roberts, C., Anderson, K. L., Murphy, E., Projan, S. J., Mounts, W., Hurlburt, B., Smeltzer, M., Overbeek, R., Disz, T., and Dunman, P. M. (2006). Characterizing the effect of the Staphylococcus aureus virulence factor regulator, SarA, on log-phase mRNA half-lives. J. Bacteriol. 188 , 2593-2603.

Schumacher, M. A., Hurlburt, B. K., and Brennan, R. G. (2001). Crystal structures of SarA, a pleiotropic regulator of virulence genes in S. aureus. Nature 409, 215-219.

Selinger, D. W., Saxena, R. M., Cheung, K. J., Church, G. M., and Rosenow, C. (2003). Global RNA half-life analysis in Escherichia coli reveals positional patterns of transcript degradation. Genome Res. 13, 216-223.
Sterba, K. M., Mackintosh, S. G., Blevins, J. S., Hurlburt, B. K., and Smeltzer, M. S. (2003). Characterization of Staphylococcus aureus SarA binding sites. J. Bacteriol. 185, 4410-4417.

Tegmark, K., Karlsson, A., and Arvidson, S. (2000). Identification and characterization of SarH1, a new global regulator of virulence gene expression in Staphylococcus aureus. Mol. Microbiol. 37, 398-409.

Wang, X., Dubey, A. K., Suzuki, K., Baker, C. S., Babitzke, P., and Romeo, T. (2005). CsrA post-transcriptionally represses pgaABCD, responsible for synthesis of a biofilm polysaccharide adhesin of Escherichia coli. Mol. Microbiol. 56, 1648-1663.

Wei, B. L., Brun-Zinkernagel, A. M., Simecka, J. W., Pruss, B. M., Babitzke, P., and Romeo, T. (2001). Positive regulation of motility and flhDC expression by the RNA-binding protein CsrA of Escherichia coli. Mol. Microbiol. 40, 245-256.

Conflict of Interest Statement: The authors declare that the research was conducted in the absence of any commercial or financial relationships that could be construed as a potential conflict of interest.

Received: 14 December 2011; accepted: 20 February 2012; published online: 08 March 2012.

Citation: Morrison JM, Anderson KL, Beenken KE, Smeltzer MS and Dunman PM (2012) The staphylococcal accessory regulator, SarA, is an RNA-binding protein that modulates the MRNA turnover properties of late-exponential and stationary phase Staphylococcus aureus cells. Front. Cell. Inf. Microbio. 2:26. doi: 10.3389/fcimb.2012.00026

Copyright (c) 2012 Morrison, Anderson, Beenken, Smeltzer and Dunman. This is an open-access article distributed under the terms of the Creative Commons Attribution Non Commercial License, which permits non-commercial use, distribution, and reproduction in other forums, provided the original authors and source are credited. 